\title{
PENERAPAN PRINSIP-PRINSIP GOOD GOVERNANCE DALAM MENINGKATKAN KUALITAS PELAYANAN PUBLIK
}

\author{
Abd. Rohman, Yayang Santrian Hanafi; Willy Tri Hardianto \\ Program Studi Administrasi Publik Fakultas Ilmu Sosial dan Ilmu Politik \\ Universitas Tribhuwana Tunggadewi \\ Email: rohmanch93@yahoo.com; yayangsantrianhanafi@gmail.com; \\ willytrihardianto@yahoo.co.id
}

\begin{abstract}
The Government's duty other than the Government conducting a public service that is characterized by good governance. In Lowokwaru, time service itself became one things to note again. This can hamper service rendered to the society. In addition to the time of service, service officer presence also the things that can hinder the effectiveness and efficiency of the public services which are given to the community. This study uses qualitative methods. Using data collection techniques interviews, observation, and documentation. Determination of sampling techniques using the purposive addition. Data was analyzed through data reduction stage, the presentation of data, and the withdrawal of the conclusion. Validity test of the data, researchers used triangulation techniques. Research results application of the principles of good governance in improving the quality of public services in Lowokwaru already going pretty well. But in some aspects still contained flaws. It a barrier among other less familiar society requirements, service officers not to enter the work, power outages, as well as the network is unstable. Things that support among other hospitality-giver services officer, completeness of facilities and infrastructure, as well as the competence of the officers the service givers.
\end{abstract}

Keywords: public service; good governance.

\begin{abstract}
Abstrak: Tugas pemerintah selain menyelenggarakan pemerintahan yaitu pelayanan publik yang bercirikan good governance. Di Kecamatan Lowokwaru, waktu pelayanan menjadi salah satu hal yang perlu diperhatikan lebih lanjut. Hal ini akan menghambat proses pemberiian layanan publik kepada masyarakat. Selain waktu pelayanan, kehadiran petugas layanan juga menjadi sebuah aspek yang dapat menghambat efektifitas dan efisiensi pelayanan kepada masyarakat. Penelitian ini menggunakan metode kualitatif. Teknik dalam pengumpulan data menggunakan wawancara, observasi, dan dokumentasi. Teknik penentuan sampling menggunakan purposive samping. Analisis data melalui tahap reduksi data, penyajian data, dan penarikan kesimpulan. Uji keabsahan data menggunakan cara triangulasi teknik. Hasil penelitian penerapan prinsip-prinsip good governance dalam meningkatkan kualitas pelayanan publik di Kecamatan Lowokwaru sudah dijalankan dengan baik. Namun demikian dalam aspek-aspek tertentu masih ditemukan kekurangan. Hal penghambat antara lain masyarakat kurang paham persyaratan, petugas pelayanan tidak masuk kerja, pemadaman listrik, serta jaringan tidak stabil. Hal yang mendukung antara lain keramahan petugas pemberi layanan, kelengkapan sarana dan prasarana, serta kompetensi petugas pemberi layanan.
\end{abstract}

Kata kunci: pelayanan publik, good governance. 


\section{PENDAHULUAN}

Pada masa transisi otonomi daerah, kesejahteraan masyarakat harus tetap dijadikan pedoman dalam perumusan peran dan tugas pemerintah. Dalam reformasi sistem pemerintahan, perumusan tentang tugas dan peran pemerintah merupakan suatu bagiannya, disamping penataan lembaga pemerintah dari pusat sampai ke daerah. Dengan adanya perumusan tentang tugas dan peranan pemerintah, maka dapat dipilah-pilah fungsi-fungsi pemerintahan dalam hal penyelengaraan pelayanan publik, dikarenakan salah satu fungsi utama dalam penyelenggaraan pemerintahan yaitu sebagai penyelenggara pelayanan publik.

Di era modernisasi seperti ini, pelayanan publik yang diberikan oleh pemerintah kepada masyarakat merupakan bentuk komitmen pemerintah dalam mensejahterakan masyarakat. Paradigma atau pandangan pergeseran sistem pemerintah yang dulu sentralistis kini telah berubah menjadi sistem desentralisasi. Sistem desentralisasi memberikan kemudahan untuk membentuk lingkungan kerja yang ideal, memperluas cakupan pelayanan publik dan partisipasi, peningkatan responsibilitas serta pengawasan dapat dilakukan secara intensif oleh pemerintah. Undang-undang Nomor 23 Tahun 2014 Terkait Pemerintahan Daerah adalah suatu peraturan yang mengatur lebih rinci pemberlakuan sistem desentralisasi di Indonesia. Dari undang-undang tersebut maka konsekuensinya sebagai daerah otonom diamanahkan kewenangan yang lebih besar dalam hal mengatur urusan rumah tangga dan kepentingan serta kebutuhan daerah tersebut. Otonomi daerah mempunyai maksud untuk mendistribusikan kewenangan agar dapat terkoordinasi secara baik.

Good governance adalah sebuah sistem yang dalam menjalankan kepemerintahan berdasar dari pola hubungan antara pemerintah, masyarakat dan dunia usaha atau swasta dalam menciptakan penyelenggaraan pemerintah dengan didukung oleh prinsip-prinsip dasar seperti kepastian hukum, akuntabilitas, transparansi, keadilan, profesionalisme, dan demokratis seperti tuntuntan pemerintahan yang bersih atau biasa disebut clean government yang diprakarsai oleh UNDP, World Bank, United Nation, dan beberapa lembaga internasional lainnya. Asas umum good governance telah diatur dalam Undang-undang Nomor 30 Tahun 2014 Tentang Administrasi Pemerintahan.

Tugas serta tanggung jawab pemerintah selain menyelenggarakan pemerintahan dan melaksanakan pembangunan ialah pelayanan publik. Pelayanan publik menjadi hal dasar yang paling penting dalam menggerakkan roda pemerintahan kekinian yang mengutamakan kedekatan pemerintahan dengan masyarakat melalui pelayanan. Lebih lanjut diatur dalam Pasal 1 ayat (1) Undang-Undang Nomor 25 Tahun 2009 Tentang Pelayanan Publik menjabarkan bahwa Pelayanan Publik merupakan kegiatan-kegiatan dalam upaya pemenuhan kebutuhan pelayanan sesuai dengan peraturan perundang-undangan bagi setiap warga negara dan penduduk atas barang, jasa dan/atau pelayanan administratif yang disediakan oleh penyelenggara layanan publik. Dengan berlakunya peraturan tersebut maka akan menimbulkan interaksi antara aparatur daerah dengan masyarakat menjadi semakin intensif. Dengan semakin meningkatnya tuntutan demokratisasi serta pengakuan akan hak asasi manusia yang menciptakan tuntutan terhadap manajemen pelayanan publik yang berkualitas, yang didasarkan prinsip good governance.

Di Kota Malang penerapan good governance dihadapkan pada berbagai kendala seperti inefisiensi yang tinggi, prosedur yang berbelit-belit, serta tidak adanya kepastian waktu dan tarif yang harus dikeluarkan dalam menyelenggarakan layanan. Seperti hasil penelitian dari Stefanus Panirengu, dkk. dengan judul Kepuasan Masyarakat Terhadap Kualitas Layanan 
Pembuatan e-KTP (Suatu Studi di Kecamatan Lowokwaru Kota Malang) yang menyatakan bahwa proses pembuatan $e-K T P$ masih panjang dan berbelit. Masyarakat sangat antusias dan mendukung atas penyelenggaraan program e-KTP, tapi eksekusi program yang masih sentralistis, terbatasnya alat-alat, kurang jelasnya jadwal perekaman, serta listrik yang sering padam menjadi hambatan dalam pemberian pelayanan publik yang cepat dan tepat. (Vyandri, Hakim, dan Panirengu, 2014).

Terlebih lagi penyelenggaraan pelayanan publik masih sangat dipengaruhi oleh subjektivitas, dalam konteks ini baik yang dimiliki oleh penyelenggara atau para pengguna. Usaha pengembangan pelayanan publik kepada masyarakat dengan memperhatikan prinsipprinsip good governance menjadi sangat penting. Prinsip-prinsip yang di maksud diantaranya adalah Transparansi/Keterbukaan, Akuntabilitas (Accountability) Pelayanan Publik, Responsivitas (Responsiveness) Pelayanan Publik, Keadilan (Fairness) yang merata, Efesiensi dan Efektivitas (Efficiency \& Effectiveness), Partisipasi (Participation) dalam pelayanan publik. Kondisi tersebut dari hasil pengamatan penulis juga terjadi di salah satu Kecamatan di Kota Malang, yaitu Kecamatan Lowokwaru.

Di Kecamatan Lowokwaru, masalah waktu pelayanan sendiri menjadi sebuah hal yang menjadi penghambat dan masih perlu diperhatikan lagi. Hal ini dapat menghambat proses pelayanan publik kepada pengguna layanan. Selain waktu pelayanan, kehadiran petugas pemberi layanan turut menjadi suatu aspek yang dapat menghambat efektifitas dan efisiensi pelayanan publik yang di berikan kepada pengguna layanan dalam hal ini masyarakat. Dengan berdasar pada uraian latar belakang di atas maka penulis tertarik untuk melakukan penelitian dengan judul: "Penerapan Prinsip-Prinsip Good Governance Dalam Meningkatkan Kualitas Pelayanan Publik Di Kecamatan Lowokwaru Kota Malang.” Tujuan dari penelitian ini adalah untuk mengetahui bagaimana penerapan prinsip-prinsip good governance dalam meningkatkan kualitas pelayanan publik di Kecamatan Lowokwaru Kota Malang dan untuk mengetahui apa saja hal-hal yang berperan didalamnya.

\section{METODE PENELITIAN}

Menurut Sugiyono (2017: 2), metode penelitian pada hakikatnya adalah suatu cara atau teknik ilmiah dalam usaha mencari data yang tujuan dan kegunaannya bersifat ilmiah. Berdasarkan pengertian tersebut maka terdapat empat aspek kunci yang patut diperhatikan yaitu, cara ilmiah, data, tujuan dan kegunaan. Cara ilmiah memiliki arti yaitu kegiatan penelitian didasarkan pada ciri-ciri keilmuan, antara lain rasional, empiris, dan sistematis. Rasional berarti kegiatan penelitian dilaksanakan menggunakan cara-cara yang masuk akal yang dapat dijangkau oleh nalar manusia. Empiris mengandung arti yaitu cara-cara yang dilakukan dapat dilihat oleh indera manusia, sehingga orang lain juga dapat mengamati serta mengetahui cara atau metode yang digunakan. Sistematis ialah suatu proses yang digunakan dalam penelitian menggunakan langkah-langkah khusus yang bersifat logis.

Penelitian ini menggunakan metode penelitian kualitatif. Berdasarkan penjelasan Moleong (2011: 6) yang dimaksud dengan penelitian kualitatif yaitu sebuah penelitian yang mempunyai tujuan untuk memahami fenomena terkait apa saja hal yang dialami oleh subjek penelitian. Penelitian ini dilaksanakan di Kantor Kecamatan Lowokwaru yang beralamatkan di Jalan Cengger Ayam I nomor 12 Kota Malang 65141.Penelitian ini menggunakan teknik sampling dengan purposive sampling. Purposive sampling merupakan suatu metode atau cara pengambilan sampel sumber data berdasarkan pertimbangan tertentu. Yang dimaksud dengan 
pertimbangan tertentu misalnya orang tersebut dianggap paling mengerti tentang hal apa yang kita harapkan, mungkin juga dia sebagai penguasa sehingga akan memudahkan peneliti mengeksplor objek ataupun situasi sosial yang akan diteliti. Setelah data diperoleh, data akan dianalisis melalui tahapan yang pertama reduksi data, kemudian penyajian data, dan terakhir penarikan kesimpulan. Uji kredibilitas data dalam menguji kevalidan data tersebut, maka peneliti menggunakan cara triangulasi teknik. Artinya mengecek data yang sudah didapatkan pada sumber yang sama namun dengan cara yang berbeda. (Sugiyono, 2017:274)

\section{HASIL DAN PEMBAHASAN}

\section{Partisipasi Masyarakat}

Menurut UNDP, badan program pembangunan PBB pada tahun 1997, partisipasi masyarakat memiliki pengertian setiap warga masyarakat, laki-laki dan perempuan wajib mempunyai hak suara yang tidak berbeda dalam proses pemilihan umum dengan kebebasan berpendapat secara konstruktif. Hal ini juga bisa diartikan adanya keaktifan masyarakat dalam kegiatan-kegiatan pemerintahan yang berhubungan dengan keberlangsungan sinergitas antara pemerintah dengan masyarakat.

Dari hasil penelitian langsung di lapangan maka peneliti mendapatkan hasil bahwa partisipasi masyarakat di Kecamatan Lowokwaru Malang sudah diterapkan dengan baik. Salah satu bukti baiknya partisipasi masyarakat yaitu dengan antusiasme masyarakat dalam mengikuti kegiatan-kegiatan sosialisasi dan juga musrenbang di Kecamatan Lowokwaru Malang.

\section{Penegakan Hukum}

Dalam rumusan prinsip-prinsip good governance yang dikemukakan oleh United Nations Development Programme pada tahun 1997, penegakkan hukum memiliki arti yaitu sebuah rangka yang dimiliki haruslah berkeadilan dan dipatuhi. Hal ini dapat diartikan bahwa dalam pemberian pelayanan publik kepada masyarakat setiap pelayan publik harus berpedoman pada peraturan-peraturan yang berlaku. Hasil penelitian langsung di lapangan yang telah dilakukan oleh peneliti menemukan bahwa pelayanan publik yang dilakukan oleh Kecamatan Lowokwaru Kota Malang sudah sesuai dengan prinsip good governance yaitu penegakan hukum.

Hal ini dibuktikan dengan sudah diterapkannya Perda Kota Malang nomor 8 tahun 2008 tentang Tupoksi Kecamatan, adanya maklumat pelayanan yang menjadi pedoman untuk memberikan pelayanan publik kepada masyarakat, serta tidak ada lagi pungutan liar ataupun gratifikasi. Dengan berpedoman pada peraturan yang berlaku maka pelayanan yang telah diselenggarakan oleh Pemerintah Kecamatan Lowokwaru kini menjadi lebih baik dan tertata.

\section{Transparansi}

United Nations Development Programme (UNDP) pada tahun 1997 menjelaskan bahwa, transparansi mempunyai arti yaitu pemerintahan harus dibangun dalamkebebasan aliran informasi yang ingin dimiliki oleh mereka yang membutuhkannya. Hal ini dapat diukur dengan seberapa mudahnya masyarakat memperoleh informasi misalnya terkait kegiatankegiatan atau anggaran-anggaran yang digunakan oleh Kecamatan Lowokwaru.

Dari hasil penelitian langsung di lapangan yang telah dilakukan oleh peneliti didapatkan hasil bahwa transparansi di Kecamatan Lowokwaru Malang sudah diterapkan 
dengan baik. Salah satu wujud transparansi di Kecamatan Lowokwaru adalah informasiinformasi di situs resmi Kecamatan Lowokwaru Malang. Selain itu juga masyarakat dapat meminta informasi langsung kepada para petugas pelayanan di Kecamatan Lowokwaru.

\section{Daya Tanggap Petugas Pemberi Layanan}

Salah satu prinsip good governance yang paling penting adalah daya tanggap petugas pemberi layanan. Dalam rumusan prinsip-prinsip good governance yang dikemukakan oleh United Nations Development Programme tahun 1997, daya tanggap memiliki arti yaitu bahwa setiap lembaga dalam prosesnya harus diarahkan kepada upaya untuk melayani berbagai pihak yang berkepentingan (masyarakat). Dari hasil penelitian langsung di lapangan yang dilakukan oleh penelitididapatkan hasil bahwa daya tanggap petugas pemberi layanan di Kecamatan Lowokwaru sudah baik.

Hal ini didukung oleh adanya Standar Operasional Prosedur yang baik dan sistematis di Kecamatan Lowokwaru Malang. Dengan adanya Standar Operasional Prosedur yang baik maka pelayanan publik di Kecamatan Lowokwaru Malang juga semakin baik. Selain itu keramahan pemberi layanan juga membuat masyarakat puas akan pelayanan yang diberikan. Hal ini juga dapat meminimalisir munculnya masalah ketika proses pemberian layanan sedang berlangsung.

\section{Berorientasi Pada Konsensus}

Sesuai dengan pengertiannya, berorientasi pada konsensus memiliki arti pemerintahan yang baik adalah pemerintahan yangdapat menjadi penengah bagi berbagai perbedaan dan memberikan suatu penyelesaian. Hal ini seperti yang dikemukakan oleh United Nations Development Programme(UNDP) pada tahun 1997. Dari hasil-hasil wawancara peneliti di lapangan didapatkan suatu kesimpulan bahwa prinsip berorientasi pada konsensus yang berarti pemerintah memberikan penyelesaian masalah sudah diterapkan di Kecamatan Lowokwaru Malang. Salah satu wujud penyelesaian masalah yang diberikan oleh petugas adalah ketika masyarakat kurang dalam hal persyaratan maka petugas pelayanan akan memberikan solusi atau arahan-arahan agar masalah tersebut dapat terselesaikan.

\section{Berkeadilan}

Prinsip good governance berkeadilan mempunyai makna memberikan pelayanan tanpa membeda-bedakan. Menurut badan program pembangunan PBB pada tahun 1997, berkeadilan memiliki arti yaitu memberikan kesempatan upaya untuk meningkatkan kualitas hidup seseorang dengan adil tanpa membedakan laki-laki atau perempuan. Dari pengertian tersebut dapat disimpulkan pada intinya dalah pemberian layanan publik yang sama rata tanpa membeda-bedakan suku, ras, agama, strata sosial, maupun jenis kelamin.

Prinsip ini telah diterapkan di Kecamatan Lowokwaru Malang. Dari hasil penelitian langsung di lapangan yang telah dilakukan oleh peneliti didapatkan hasil yang menunjukkan bahwa prinsip good governance berkeadilan sudah diterapkan di Kecamatan Lowokwaru Malang. Hal ini bisa berjalan dengan baik karena adanya kesadaran para petugas pemberi layanan dan juga didukung oleh arahan dari Camat Lowokwaru.

Hal ini berbeda dengan hasil penelitian terdahulu yang dilakukan oleh Shinta Tomuka (2013) yang menyakatan bahwa dalam penerapan prinsip-prinsip Good Governance dalam pelayanan publik,terutama prinsip Partisipasi, ketentuan danaturan-aturan yang berlaku, 
prinsip transparansi, dan prinsip responsif Camat telah memberikan yang terbaik, walaupunada beberapa warga menurut hasilwawancara mengatakan Camat cenderung pilih kasih terhadap wargayang berkemampuan secara finansial danwarga yang kurang berkemampuan.

\section{Efektifitas dan Efisiensi Pelayanan}

Efektifitas dan efisiensi merupakan salah satu dari prinsip good governance yang harus diterapkan agar pelayanan menjadi lebih baik. Menurut United Nations Development Programme pada tahun 1997, efektivitas dan efisiensi yaitu bahwa setiap proses kegiatan dan kelembagaan diarahkan dalam upaya menghasilkan suatu yang benar-benar dibutuhkan.

Dari hasil penelitian langsung di lapangan yang telah dilakukan oleh peneliti maka didapatkan hasil bahwa penerapan prinsip good governance efektifitas dan efisiensi di Kecamatan Lowokwaru sudah diterapkan dengan baik. Hanya saja terdapat beberapa kendala insidentil misalnya ketika ada salah satu petugas pelayanan tidak masuk maka pelayanan akan sedikit terhambat.

\section{Akuntabilitas}

Akuntabilitas adalah pertanggungjawaban pemerintah kepada publik. Akuntabilitas termasuk dalam salah satu prinsip good governance yang harus diterapkan dalam pemerintahan. Menurut UNDP, badan program pembangunan PBB pada tahun 1997, akuntabilitas memiliki pengertian yaitu bahwa para pengambil keputusan dalam pemerintah dapat memiliki pertanggungjawaban kepada publik. Dari hasil penelitian langsung di lapangan, peneliti mendapatkan hasil yang menyatakan bahwa salah satu prinsip good governance yaitu akuntabilitas sudah diterapkan dengan baik di Kecamatan Lowokwaru.

Hal ini dapat dibuktikan dengan kemudahan masyarakat dalam memperoleh informasi terkait pelaksanaan kegiatan dan pelaporan anggaran yang dapat kita lihat langsung melalui laman resmi Kecamatan Lowokwaru Malang. Akan tetapi masih terdapat beberapa kendala dalam membuka situs resmi Kecamatan Lowokwaru seperti terkadang server down sehingga situs tidak dapat terbuka.

\section{Bervisi Strategis}

Menurut United Nations Development Programme (UNDP), badan program pembangunan PBB pada tahun 1997, prinsip terakhir dari good governance adalah bervisi strategis. Bervisi strategis memiliki arti para pimpinan dan masyarakat memiliki pandangan yang luas dan jangka panjang tentang penyelenggaraan pemerintahan yang baik dan pembangunan manusia. Dalam hal ini kesamaan visi dan misi antar internal Kecamatan Lowokwaru harus terjaga agar visi dan misi di masa depan dapat tercapai dan dapat tercapai sesuai dengan apa yang di cita-citakan. Dari hasil penelitian langsung di lapangan yang telah dilakukan oleh peneliti dapat disimpulkan bahwa Kecamatan Lowokwaru sudah menerapkan prinsip terakhir dari good governance yaitu bervisi strategis.

Salah satu bentuk visi strategis yang diterapkan Kecamatan Lowokwaru terkait pelayanan prima yaitu penyebaran informasi persyaratan pelayanan yang pada awalnya hanya melalui papan pengumuman kemudian berpindah ke sosialisasi-sosialisasi bahkan hingga melalui media sosial dan laman resmi Kecamatan Lowokwaru. Akan tetapi hubungan antara masyarakat dengan Pemerintah Kecamatan Lowokwaru masih harus lebih ditingkatkan lagi 
agar visi misi dapat tersampaikan kepada masyarakat dengan baik dan dapat tercapai sesuai dengan harapan.

\section{Hal-Hal Penghambat Penerapan Prinsip-Prinsip Good Governance Dalam Meningkatkan Kualitas Pelayanan Publik di Kecamatan Lowokwaru}

Dari hasil penelitian langsung di lapangan yang telah dilakukan oleh peneliti ditemukan hasil bahwa masih terdapat beberapa hal yang dapat menghambat antara lain masyarakat kurang paham persyaratan pelayanan, petugas pelayanan yang izin tidak masuk kerja, pemadaman listrik, serta jaringan kurang lancar atau stabil.

Dari hal-hal yang menghambat penerapan prinsip-prinsip good governance dalam meningkatkan kualitas pelayanan publikdi Kecamatan Lowokwaru Malang ini dapat dilakukan beberapa tindakan untuk mengatasinya. Misalkan dengan lebih sering mengadakan sosialisasi terkait persyaratan pelayanan atau dapat juga dengan memasang spanduk-spanduk persyaratan pelayan di tiap sudut-sudut strategis di wilayah Kecamatan Lowokwaru Malang untuk memberikan kemudahan informasi terkait persyaratan pelayanan kepada masyarakat.

Kemudian dengan membuat peraturan internal terkait ijin tidak masuk kerja serta membuat solusi misalnya dengan pergeseran posisi sementara ketika ada salah satu petugas pelayanan yang tidak masuk kerja agar proses pemberian layanan tetap dapat berjalan dengan lancar. Untuk mengantisipasi terjadinya pemadaman listrik, Pemerintah Kecamatan Lowokwaru hendaknya menyediakan tenaga listrik pengganti atau genset agar proses pelayanan publik tidak terganggu. Serta Pemerintah Kecamatan Lowokwaru harus meningkatkan kerjasama dengan dinas terkait yang menangani tentang jaringan agar masalah jaringan tidak stabil dapat diatasi.

\section{Hal-Hal Pendukung Penerapan Prinsip-Prinsip Good Governance Dalam Meningkatkan Kualitas Pelayanan Publik di Kecamatan Lowokwaru}

Dari hasil penelitian langsung di lapangan, hal-hal yang dapat mendukung penerapan prinsi-prinsip good governance dalam meningkatkan kualitas pelayanan publik di Kecamatan Lowokwaru Kota Malang yaitu pertama adalah keramahan petugas pemberi layanan. Keramahan petugas pemberi layanan merupakan salah satu hal penting yang mendukung dalam usaha meningkatkan kualitas pelayanan publik di Kecamatan Lowokwaru Kota Malang.

Kedua adalah kelengkapan sarana dan prasarana. Kecamatan Lowokwaru memiliki sarana serta prasarana yang cukup lengkap sehingga proses pelayanan publik kepada masyarakat dapat berlangsung dengan baik. Yang terakhir adalah kompetensi petugas pemberi layanan. Dengan petugas pemberi layanan yang berkompeten maka pemberian pelayanan publik kepada masyarakat dapat berlangsung dengan baik.

\section{KESIMPULAN}

Penerapan prinsip-prinsip good governance dalam meningkatkan kualitas pelayanan publik di Kecamatan Lowokwaru Kota Malang telah dilaksanakan dengan lumayan baik. Akan tetapi di beberapa bagian masih ditemukan kekurangan, baik kekurangan dari pegawai Kecamatan Lowokwaru, maupun kekurangan dari sistem sebagai sarana pemberian layanan publik yang baik kepada masyarakat. Hal-hal yang menjadi penghambat antara lain masyarakat kurang paham persyaratan pelayanan, petugas pelayanan yang izin tidak masuk 
kerja, pemadaman listrik, serta jaringan internet yang kurang stabil. Sedangkan hal-hal yang menjadi pendukung antara lain keramahan petugas pemberi layanan, kelengkapan sarana dan prasarana, serta kompeten atau tidaknya petugas kecamatan selaku pihak yang memberikan pelayanan.

\section{DAFTAR PUSTAKA}

Badudu J.S dan Zain, Sutan Mohammad. 1996. Kamus Umum Bahasa Indonesia. Jakarta: Pustaka Sinar Harapan.

Hardiansyah. 2011. Kualitas Pelayanan Publik. Yogyakarta: Gava Media.

Kamus Besar Bahaasa Indonesia (KBBI) Online Pengertian Penerapan. https://kbbi.web.id/terap-2, diakses 16 Oktober 2018.

Kriyantono, Rachmat. 2012. PR Writting: Tehnik Produksi Media Publik Relations dan Publisitas Korporat. Jakarta: Kencana.

Lembaga Administrasi Negara. 2003. SANKRI: Buku 1 Prinsip-Prinsip Penyelenggaraan Negara. Penerbit: Lembaga Administrasi Negara

Panirengu, dkk. 2014. Kepuasan Masyarakat Terhadap Kualitas Layanan Pembuatan e-KTP (Studi di Kecamatan Lowokwaru Malang). Jurnal Administrasi Publik (Online), 2 (2): 189-194, (http://administrasipublik.studentjournal.ub.ac.id), diakses 18 Oktober 2018.

Sedarmayanti. 2009. Reformasi Administrasi Publik, Reformasi Birokrasi, Dan Kepemimpinan Masa Depan: Mewujudkan Pelayanan Prima Serta Kepemerintahan Yang Baik. Bandung: Refika Aditama.

Sinambela, Lijan Poltak. dkk. 2011. Reformasi Pelayanan Publik. Jakarta: Bumi Aksara Undang Undang Nomor 25 Tahun 2009 Terkait Pelayanan Publik.

Undang-Undang Nomor 23 Tahun 2014 Terkait Pemerintahan Daerah.

Undang-Undang Nomor 30 Tahun 2014 Terkait Administrasi Pemerintahan.

Yamit, Zulian. 201O. Management Kualitas Produk dan Jasa. Yogyakarta: Penerbit Ekonisia. 